\title{
Morphological and Physiological Alterations InduCed by LACTOFEN IN SOYbean LEAVES ARE REDUCEd WITH NITRIC OXIDE ${ }^{1}$
}

\author{
Alterações Morfológicas e Fisiológicas Induzidas por Lactofen em Folhas de Soja são Reduzidas \\ com o Óxido Nítrico
}

\author{
FERREIRA, L.C. ${ }^{2}$, CATANEO, A.C. ${ }^{3}$, REMAEH, L.M.R. ${ }^{4}$, BÚFALO, J. ${ }^{5}$, SCAVRONI, J. ${ }^{6}$, \\ ANDRÉO-SOUZA, Y..$^{7}$, CECHIN, I. ${ }^{8}$ and SOARES, B.J.A. ${ }^{9}$
}

\begin{abstract}
Lactofen is a diphenylether herbicide recommended to control broad-leaved weeds in soybean (Glycine max) fields and its mechanism of action is the inhibition of protoporphyrinogen-IX oxidase (Protox), which acts in the chlorophyll biosynthesis. This inhibition results in an accumulation of protoporphyrin-IX, which leads to the production of reactive oxygen species (ROS) that cause oxidative stress. Consequently, spots, wrinkling and leaf burn may occur, resulting in a transitory crop growth interruption. However, nitric oxide (NO) acts as an antioxidant in direct ROS scavenging. Thus, the aim of this work was to verify, through phytometric and biochemical evaluations, the protective effect of NO in soybean plants treated with the herbicide lactofen. Soybean plants were pre-treated with different levels of sodium nitroprusside (SNP), a NO-donor substance, and then sprayed with $168 \mathrm{~g}$ a.i. ha-1 lactofen. Pre-treatment with SNP was beneficial because NO decreased the injury symptoms caused by lactofen in young leaflets and kept low the soluble sugar levels. Nevertheless, NO caused slower plant growth, which indicates that further studies are needed in order to elucidate the action mechanisms of NO in signaling the stress caused by lactofen in soybean crop.
\end{abstract}

Keywords: Glycine max, oxidative stress, plant growth, soluble sugars.

\begin{abstract}
RESUMO - O lactofen é um herbicida difeniléter recomendado para controlar plantas daninhas de folhas largas em campos de soja (Glycine max) e seu mecanismo de ação é a inibição da protoporfirinogênio-IX oxidase (Protox), que atua na biossintese de clorofilas. Essa inibição resulta em um acúmulo de protoporfirina- $I X$, o que leva à produção de espécies reativas de oxigênio (ROS), causando estresse oxidativo. Conseqüentemente, podem ocorrer manchas, enrugamento e queima das folhas, o que leva à paralisação temporária do crescimento da cultura. Porém, o óxido nitrico (NO) atua como um antioxidante na eliminação direta das ROS. Assim, o objetivo deste trabalho foi verificar, por meio de avaliações fitométricas e bioquímicas, o efeito protetor do NO em plantas de soja tratadas com o herbicida lactofen. Plantas de soja foram pré-tratadas com diferentes doses de Nitroprussiato de Sódio (SNP), substância doadora de NO, e então pulverizadas com $168 \mathrm{~g}$ a.i. ha-1 lactofen. O prétratamento com SNP foi benéfico, pois o NO reduziu os sintomas de injúria causados pelo lactofen nos foliolos jovens e manteve baixos teores de açúcares solúveis. Porém, o NO proporcionou crescimento mais lento das plantas. Desta forma, posteriores estudos são necessários para elucidar os mecanismos de ação do NO na sinalização do estresse promovido pelo lactofen na cultura da soja.
\end{abstract}

Palavras-chave: Glycine max, estresse oxidativo, crescimento vegetal, açúcares solúveis.

Recebido para publicação em 9.2.2011 e aprovado em 19.4.2011.

2 Biólogo, D.Sc., Universidade Estadual Paulista - IBB/UNESP, 18618-000 Botucatu-SP, <ferreira.leonardocesar@gmail.com>; ${ }^{3}$ Bióloga, Ph.D., Professora, IBB/UNESP; ${ }^{4}$ Bióloga, D.Sc., IBB/UNESP; ${ }^{5}$ Bióloga, Estudante de Mestrado em Horticultura, FCA/UNESP, 18610-307 Botucatu-SP, ${ }^{6}$ Bióloga, D.Sc., IBB/UNESP, ${ }^{7}$ Bióloga, Ph.D., IBB/UNESP, ${ }^{8}$ Bióloga, Ph.D., Professora, FC/UNESP, 17033-360 Bauru-SP; ${ }^{9}$ Biólogo, IBB/UNESP.

Planta Daninha, Viçosa-MG, v. 29, n. 4, p. 837-847, 2011 


\section{INTRODUCTION}

Reactive chemical intermediates derived from several substances have been considered agents that lead to many phytotoxicological mechanisms (Halliwell \& Gutteridge, 1984). Among them, reactive oxygen species (ROS), represented by superoxide radicals $\left(\mathrm{O}_{2}^{-}\right)$, hydroxyl radicals $(\mathrm{OH})$, hydrogen peroxide $\left(\mathrm{H}_{2} \mathrm{O}_{2}\right)$, and singlet oxygen $\left({ }^{1} \mathrm{O}_{2}\right)$, are the most important compounds in biological systems due to their abundance and interconvertibility (Beligni \& Lamattina, 1999a).

Excessive ROS levels result in damages to the photosynthetic apparatus through photoinhibition, causing severe cellular injuries and leaf chlorosis (van Breusegem et al., 2001). Thus, the control of endogenous ROS levels has raised the possibility of using these species as signaling molecules in growth, development, stress responses, and biotic interactions (Mittler et al., 2004). ROS formation can be induced by several xenobiotics such as irradiation, atmospheric pollution, ozone, or pathogens (Beligni \& Lamattina, 1999a).

Some herbicides, like lactofen $\{2-$ ethoxy-1-methyl-2-oxoethyl 5-[2-chloro-4(trifluoromethyl)phenoxy]-2-nitrobenzoate\}, present ROS generation as mechanism of action, causing oxidative stress in the plants. Lactofen is a diphenylether herbicide recommended for weed control in soybean (Glycine max) crop (Rodrigues \& Almeida, 1998). Diphenylethers inhibit the enzyme protoporphyrinogen-IX oxidase (Protox, EC 1.3.3.4), which catalyses the oxidation of protoporphyrinogen-IX to protoporphyrin-IX (proto-IX) during chlorophyll biosynthesis (Matringe et al., 1989). This inhibition is followed by an abnormal proto-IX accumulation and then leads to the formation of short-chain hydrocarbons like ethane, resulting in loss of plant coloration and death. Hydrocarbons are formed due to the action of ROS. The latter compounds are originated from molecular oxygen through proto-IX accumulation in the presence of light, which causes photooxidative destruction of plant membranes (Watanabe et al., 2001).

Lactofen may reduce the height of soybean plants and injury symptoms may appear, including wrinkling of developing leaflets and red-orange spots in the leaves. Spot coalescence and dehydration cause tissue necrosis. Leaf blight is the final symptom and results in a transitory interruption of the crop growth, which usually restarts after three or four weeks (Damião Filho et al., 1992; Roman, 2000).

On the other hand, nitric oxide (NO), which is enzymatically produced in plant cells, protects plants against ROS generated by some herbicides. Thus, NO was reported to counteract ROS phytotoxicity in potato plants (Beligni \& Lamattina, 1999b) and rice leaves (Hung et al., 2002) treated with the herbicides diquat and paraquat.

Since NO is a highly reactive free radical, it can scavenge other reactive intermediates and end chain-propagated reactions (Beligni \& Lamattina, 1999c; Leshem, 2000; van Breusegem et al., 2001). NO is also involved in plant growth and development (Beligni \& Lamattina, 2001; Lamattina et al., 2003). This control by NO may occur throughout the plant cycle, from germination (Beligni \& Lamattina, 2000) to flowering, fruit maturing and organ senescence (Floryszak-Wieczorek et al., 2006). Besides, Del Río et al. (2004) stated that NO can act in root organogenesis, stomatal movements, senescence, programmed cell death, cell wall lignification, and nodular metabolism. Ferreira \& Cataneo (2010) also described some aspects of NO action in plants such as chemical properties, synthesis pathways, antioxidant action, signal transduction, interaction with plant hormones, and gene expression.

Beligni \& Lamattina (2001) reported several physiological effects of NO according to the plant organ in several species. In peas, NO led to senescence delay and leaf expansion. In potato stems, it inhibited internodal elongation under low luminosity and induced de-etiolation in wheat and barley. Those authors also stated that NO caused maize root elongation and induced lateral and adventitious root formation in cucumber and lavender.

There are several biochemical indicators for oxidative stress detection in plants, among them is soluble sugar measurement. Soluble 
sugars can have defense signals and responses useful to plants for controlling not only the photosynthetic activity but also the ROS level. Consequently, soluble sugars can regulate the defense against several ROS-producing stresses, such as those caused by xenobiotics (Couée et al., 2006). Besides, glucose, a reducing soluble sugar, is the main initial carbonic precursor for carotenoid (Pallet \& Young, 1993) and ascorbate (Smirnoff et al., 2001) biosynthesis, as well as for amino acid carbonic skeletons, including cysteine, glutamate, and glycine, which are glutathione components (Noctor \& Foyer, 1998). All these compounds are involved in defenses against oxidative stress through ascorbateglutathione cycles, as well as in redox reaction homeostasis and peroxide detoxification (Couée et al., 2006). In addition, specific amino acids such as histidine, methionine, and tryptophan can be oxidized by $\mathrm{O}_{2}^{-}$(van Breusegem et al., 2001).

Thus, the aim of this work was to verify, through phytometric and biochemical evaluations, the protective effect of NO in soybean plants treated with the herbicide lactofen. Phytometric measurements included plant height, root length, leaflet number, and dry matter of leaf blades, stems plus petioles, roots, and total dry matter. As regards the biochemical indicators of oxidative stress, total and reducing soluble sugar levels were measured in the dry matter of different organs.

\section{MATERIALS AND METHODS}

\section{Plant materials and growth condition}

Fifteen soybean (Glycine max) seeds cv. Pintado were sown in 8L-pots filled with the substratum "Rendmax Floreira" which is composed of: a) percentage in dry matter: 1.08 $\mathrm{N} ; 0.40 \mathrm{P}_{2} \mathrm{O}_{5} ; 0.21 \mathrm{~K}_{2} \mathrm{O} ; 14.00$ humidity; 58.00 organic matter; $32.23 \mathrm{C}$; $0.59 \mathrm{Ca} ; 1.04 \mathrm{Mg}$; $0.25 \mathrm{~S}$; b) mg. $\mathrm{kg}^{-1}$ dry matter: $240 \mathrm{Na} ; 54 \mathrm{Cu}$; $8,150 \mathrm{Fe} ; 88 \mathrm{Mn} ; 112 \mathrm{Zn}$. C/N ratio was 29/1; $\mathrm{pH}\left(\mathrm{CaCl}_{2}\right)$ was 4.94 . Pots were kept at $31-35^{\circ} \mathrm{C}$ and $52.8 \%$ relative humidity. Before treatments, a thinning was done to obtain ten plants per pot. The experiment was carried out in a greenhouse between January and March 2006 until harvestings, height and root length measurement, and leaflet number count in soybean plants. Then, dry matter quantification and biochemical evaluations were performed in the lab.

\section{Experimental design}

Pots were distributed in a completely randomized experimental design, in a $4 \times 2$ factorial arrangement, i.e. four sodium nitroprusside (SNP, Sigma-Aldrich, St. Louis, MO, USA) levels $x$ two harvesting times, with four replicates, totaling 32 pots. SNP was used as NO-donor and its levels were equivalent to $0,50,100$, and $200 \mu \mathrm{M}$. Harvesting times corresponded to 7 and 14 days after lactofen application (DALA).

\section{SNP and lactofen application}

Treatments were applied when soybean plants were in V3 phenological stage. Plants were sprayed with the above-mentioned SNP levels for two consecutive days, at $24 \mathrm{~h}$ intervals. Controls $(0 \mu \mathrm{M}$ SNP) received distilled water. On the third day, $24 \mathrm{~h}$ after the last SNP application, all plants were sprayed with lactofen at the recommended rate for soybean crop, equivalent to $168 \mathrm{~g}$ a.i. $\mathrm{ha}^{-1}$. Applications were performed by using a motorized knapsack mistblower equipped with four flat-fan nozzles (XR 110.02) at $50 \mathrm{~cm}$ height and calibrated to spray 200 liter $\mathrm{ha}^{-1}$ at $310.27 \mathrm{KPa}$ and $1 \mathrm{~m} \mathrm{~s}^{-1}$ speed.

\section{Harvestings}

At 7 and 14 DALA, plants were harvested, washed for substratum removal, and evaluated as to height, root length, and leaflet number. Then, plants were separated into leaf blades, stems plus petioles, and roots, which were placed in paper bags and stored in forced aeration oven at $60^{\circ} \mathrm{C}$ for seven days. After dry matter measurement, the material was ground and stored until evaluations of biochemical indicators of oxidative stress.

\section{Plant height, root length, and leaflet number}

Soybean plant height was defined as the distance $(\mathrm{cm})$ from the base to the apex of the 
stem. Root length corresponded to the distance $(\mathrm{cm})$ from the base to the inferior extremity of the root. Both results were expressed as the mean values of ten plants. Leaflet number consisted of all counted units.

\section{Dry matter}

Leaf blade dry matter (g) was defined as the sum of all group-dried units from all plants in each pot. The same procedure was adopted for stems plus petioles and root dry matter measurement. Total dry matter corresponded to the sum of dry matters from the different organs in each pot.

\section{Extraction and quantification of total and reducing soluble sugars}

For soluble sugar extraction, dry matter (100 mg) of each sample was placed in assay tubes containing boiling water $(10 \mathrm{ml})$. Tubes were kept in water bath at $35^{\circ} \mathrm{C}$ for $30 \mathrm{~min}$. After filtered in sterile cotton, the extracted volume was completed to $25 \mathrm{~mL}$ with distilled water and used for total and reducing soluble sugar quantification (Crepaldi et al., 2001). Total soluble sugars were estimated through the phenol-sulfuric method (Dubois et al., 1956), whereas reducing sugars were assessed through Somogy-Nelson (1945) method. Absorbance was read in Ultrospec 2000 UVvisible spectrophotometer (Amersham Pharmacia Biotech, Piscataway, NJ, USA) at 490 and $500 \mathrm{~nm}$, respectively. In both cases, glucose (Sigma-Aldrich, St. Louis, MO, USA) was used as standard, and results were expressed as total or reducing soluble sugar percentage in dry matter.

\section{Injury visual evaluations}

At 2, 4, and 7 DALA, the pots with replicates that, visually, best indicated the behavior observed in each treatment were photographed. Since young trifoliolate leaves presented visual differences, they were also photographed by following the same procedure.

\section{Statistical analysis}

All obtained results were subjected to analysis of variance (two-way ANOVA) through
F-test $(\mathrm{p}<0.05)$ by using SAS software (SAS, 1996). Then, polynomial regression models were elaborated when significant interaction between SNP $(\mu \mathrm{M})$ levels + lactofen (168 $\mathrm{g}$ a.i.ha $\left.{ }^{-1}\right) \times$ DALA was detected. When there was such an interaction but no effect of a specific SNP level + lactofen overtime, only points were plotted in the graphs. When that interaction was not detected, bar diagrams were used instead of polynomial regression models.

\section{RESULTS AND DISCUSSION}

A significant interaction between SNP levels + lactofen x DALA was observed for total (except in the roots) and reducing soluble sugars. On the other hand, no interaction was detected in height, root length, leaflet number, and dry matter of soybean plants (Table 1).

Pretreatment with SNP did not influence the height of soybean plants treated with lactofen (Figure 1). All plants had height increase at 14 DALA. Similarly, Barros et al. (2000) reported that application of $150 \mathrm{~g}$ a.i.ha ${ }^{1}$ lactofen, practically equivalent to the level used in the present study, did not reduce the height of soybean plants cv. Conquista. However, Damião Filho et al. (1992) stated that lactofen can lead to a height decrease in soybean plants.

In the present study, plants that were not pretreated with SNP tended to present higher root growth between 7 and 14 DALA (Figure 2). Slighter increases were detected in those plants pretreated with 50 and $100 \mu \mathrm{M}$ SNP, and no increase was observed with the highest level $(200 \mu \mathrm{M})$. These results suggest that NO delayed root growth in soybean plants depending on the SNP level used as pretreatment. It must be emphasized that Protox-inhibitor herbicides, such as lactofen, are not systemic. Thus, plant necrosis caused by their application is only observed in sites that received the herbicide (Merotto Junior \& Vidal, 2001), which supports the fact that lactofen was not harmful to root growth in the soybean plants of the present study. However, higher root growth due to SNP application was expected, since literature indicates that NO is involved in cell elongation induction, similarly to auxin, suggesting its mediation 
Table 1 - Analysis of variance for height, root length, leaflet number, soluble sugars, and dry matter in soybean (Glycine max) plants pretreated with different levels of SNP, followed by lactofen $(\mathrm{X})$, at two harvesting times $(\mathrm{Y})$

\begin{tabular}{|c|c|c|c|c|c|c|c|c|c|c|c|}
\hline \multicolumn{4}{|c|}{ Height } & \multicolumn{4}{|c|}{ Root length } & \multicolumn{4}{|c|}{ Leaf number } \\
\hline & $\mathrm{X}$ & $\mathrm{Y}$ & $\mathrm{X}^{*} \mathrm{Y}$ & & $\mathrm{X}$ & $\mathrm{Y}$ & $\mathrm{X} * \mathrm{Y}$ & & $\mathrm{X}$ & $\mathrm{Y}$ & $\mathrm{X}^{*} \mathrm{Y}$ \\
\hline $\mathrm{F}$ & 1.18 & 204.29 & 0.97 & $\mathrm{~F}$ & 0.56 & 21.23 & 1.43 & $\mathrm{~F}$ & 1.92 & 48.19 & 0.48 \\
\hline $\operatorname{Pr}>F$ & $0.3375^{\mathrm{NS}}$ & $<0.0001^{*}$ & $0.4236^{\mathrm{NS}}$ & $\operatorname{Pr}>F$ & $0.6483^{\mathrm{NS}}$ & $0.0001^{*}$ & $0.2599^{\mathrm{NS}}$ & $\operatorname{Pr}>F$ & $0.1537^{\mathrm{NS}}$ & $<0.0001^{*}$ & $0.6982^{\mathrm{NS}}$ \\
\hline $\mathrm{CV} \%$ & \multicolumn{3}{|c|}{7.85} & $\mathrm{CV} \%$ & \multicolumn{3}{|c|}{7.46} & CV\% & \multicolumn{3}{|c|}{16.31} \\
\hline \multicolumn{12}{|c|}{ Total soluble sugars } \\
\hline \multicolumn{4}{|c|}{ leaf blades } & \multicolumn{4}{|c|}{ stems plus petioles } & \multicolumn{4}{|c|}{ roots } \\
\hline & $\mathrm{X}$ & $\mathrm{Y}$ & $\mathrm{X} * \mathrm{Y}$ & & $\mathrm{X}$ & $\mathrm{Y}$ & $\mathrm{X} * \mathrm{Y}$ & & $\mathrm{X}$ & $\mathrm{Y}$ & $\mathrm{X} * \mathrm{Y}$ \\
\hline $\mathrm{F}$ & 2.95 & 10.59 & 12.26 & $\mathrm{~F}$ & 1.85 & 11.12 & 4.95 & $\mathrm{~F}$ & 5.62 & 1.49 & 0.95 \\
\hline $\operatorname{Pr}>\mathrm{F}$ & $0.0529^{\mathrm{NS}}$ & $0.0034 *$ & $<0.0001^{*}$ & $\operatorname{Pr}>\mathrm{F}$ & $0.1646^{\mathrm{NS}}$ & $0.0028 *$ & $0.0082 *$ & $\operatorname{Pr}>\mathrm{F}$ & $0.0046^{*}$ & $0.2344^{\mathrm{NS}}$ & $0.4306^{\mathrm{NS}}$ \\
\hline $\mathrm{CV} \%$ & \multicolumn{3}{|c|}{20.05} & CV\% & \multicolumn{3}{|c|}{42.59} & CV\% & \multicolumn{3}{|c|}{28.17} \\
\hline \multicolumn{12}{|c|}{ Reducing soluble sugars } \\
\hline \multicolumn{4}{|c|}{ leaf blades } & \multicolumn{4}{|c|}{ stems plus petioles } & \multicolumn{4}{|c|}{ roots } \\
\hline & $\mathrm{X}$ & $\mathrm{Y}$ & $\mathrm{X} * \mathrm{Y}$ & & $\mathrm{X}$ & $\mathrm{Y}$ & $\mathrm{X} * \mathrm{Y}$ & & $\mathrm{X}$ & $\mathrm{Y}$ & $\mathrm{X}^{*} \mathrm{Y}$ \\
\hline $\bar{F}$ & 15.51 & 7.75 & 6.74 & $\bar{F}$ & 60.83 & 87.36 & 39.51 & $\mathrm{~F}$ & 11.79 & 10.50 & 4.20 \\
\hline $\operatorname{Pr}>\mathrm{F}$ & $<0.0001^{*}$ & $0.0103^{*}$ & $0.0019^{*}$ & $\operatorname{Pr}>\mathrm{F}$ & $<0.0001^{*}$ & $<0.0001^{*}$ & $<0.0001^{*}$ & $\operatorname{Pr}>\mathrm{F}$ & $<0.0001^{*}$ & $0.0035^{*}$ & $0.0159^{*}$ \\
\hline $\mathrm{CV} \%$ & \multicolumn{3}{|c|}{18.38} & CV\% & \multicolumn{3}{|c|}{23.69} & CV\% & \multicolumn{3}{|c|}{21.50} \\
\hline \multicolumn{12}{|c|}{ Dry matter } \\
\hline \multicolumn{4}{|c|}{ leaf blades } & \multicolumn{4}{|c|}{ stems plus petioles } & \multicolumn{4}{|c|}{ roots } \\
\hline & $\mathrm{X}$ & $\mathrm{Y}$ & $\mathrm{X} * \mathrm{Y}$ & & $\mathrm{X}$ & $\mathrm{Y}$ & $\mathrm{X} * \mathrm{Y}$ & & $\mathrm{X}$ & $\mathrm{Y}$ & $\mathrm{X} * \mathrm{Y}$ \\
\hline $\mathrm{F}$ & 0.58 & 57.36 & 1.66 & $\mathrm{~F}$ & 0.04 & 162.38 & 1.27 & $\mathrm{~F}$ & 0.69 & 78.21 & 0.29 \\
\hline $\operatorname{Pr}>\mathrm{F}$ & $0.6329^{\mathrm{NS}}$ & $<0.0001^{*}$ & $0.2028^{\mathrm{NS}}$ & $\operatorname{Pr}>\mathrm{F}$ & $0.9873^{\mathrm{NS}}$ & $<0.0001^{*}$ & $0.3056^{\mathrm{NS}}$ & $\operatorname{Pr}>\mathrm{F}$ & $0.5693^{\mathrm{NS}}$ & $<0.0001^{*}$ & $0.8297^{\mathrm{NS}}$ \\
\hline $\mathrm{CV} \%$ & \multicolumn{3}{|c|}{15.33} & CV\% & \multicolumn{3}{|c|}{14.10} & $\mathrm{CV} \%$ & \multicolumn{3}{|c|}{16.48} \\
\hline & & & & \multicolumn{4}{|c|}{ Total dry matter } & & & & \\
\hline & & & & & $\mathrm{X}$ & $\mathrm{Y}$ & $\mathrm{X} * \mathrm{Y}$ & & & & \\
\hline & & & & $\mathrm{F}$ & 0.21 & 106.93 & 1.28 & & & & \\
\hline & & & & $\operatorname{Pr}>\mathrm{F}$ & $0.8893^{\mathrm{NS}}$ & $<0.0001^{*}$ & $0.3052^{\mathrm{NS}}$ & & & & \\
\hline & & & & CV\% & & 14.36 & & & & & \\
\hline
\end{tabular}

Significant $(\mathrm{p}<0.05)$. Ns non significant.

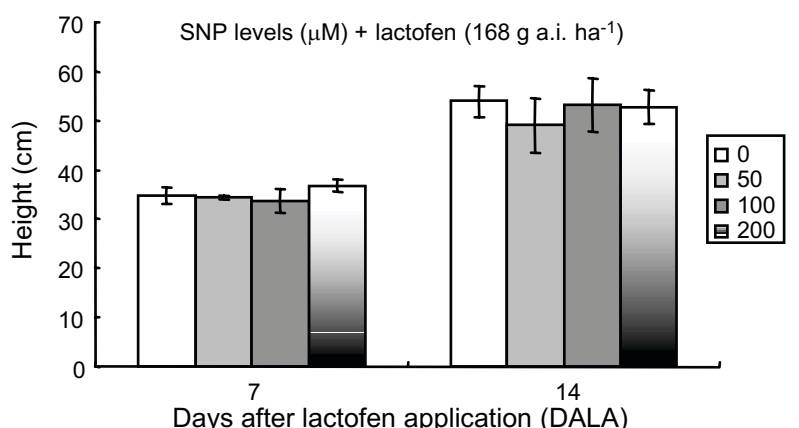

Figure 1 - Height (cm) of soybean (Glycine max) plants pretreated with $\operatorname{SNP}(0,50,100$, and $200 \mu \mathrm{M})$, followed by lactofen $\left(168 \mathrm{~g}\right.$ a.i. ha $\left.{ }^{-1}\right)$, at 7 and 14 days after lactofen application (DALA). Means of four replicates.

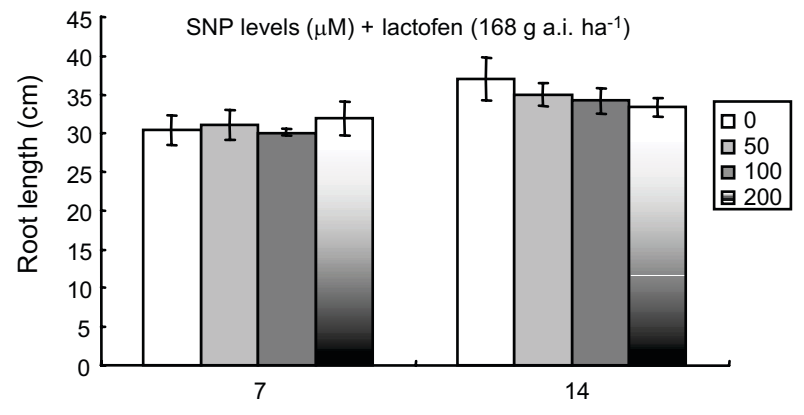

Days after lactofen application (DALA)

Figure 2 - Root length (cm) of soybean (Glycine max) plants pretreated with $\operatorname{SNP}(0,50,100$, and $200 \mu \mathrm{M})$, followed by lactofen (168 g a.i. ha $\left.{ }^{-1}\right)$, at 7 and 14 days after lactofen application (DALA). Means of four replicates.

Planta Daninha, Viçosa-MG, v. 29, n. 4, p. 837-847, 2011 
in the response to auxin in this process (Gouvêa et al., 1997). Also, Pagnussat et al. (2002) reported that NO is necessary for root formation in cucumber; thus, a transitory increase in NO concentration is involved in the adventitious root development induced by indoleacetic acid. Other studies also emphasized the importance of NO for root growth. Hu et al. (2005) described NO participation in the gravitropic curvature in soybean roots, since NO was accumulated in the primary root as a response to gravitational stimuli. Kopyra \& Gwózdz (2003) detected that NO decreased the negative influence of heavy metals such as lead and iron, besides salinity, ethylene, and paraquat herbicide on Lupinus luteus root growth.

SNP-pretreated plants had larger leaflet number, mainly at 7 DALA (Figure 3). Thus, NO clearly reduced the leaf abscission caused by lactofen. In addition, lactofen altered the young trifoliolate soybean leaves, which presented wrinkling and dark coloration at 2, 4, and 7 DALA (Figure 4). Such injuries gradually reduced with increasing SNP levels applied as pretreatment. However, no

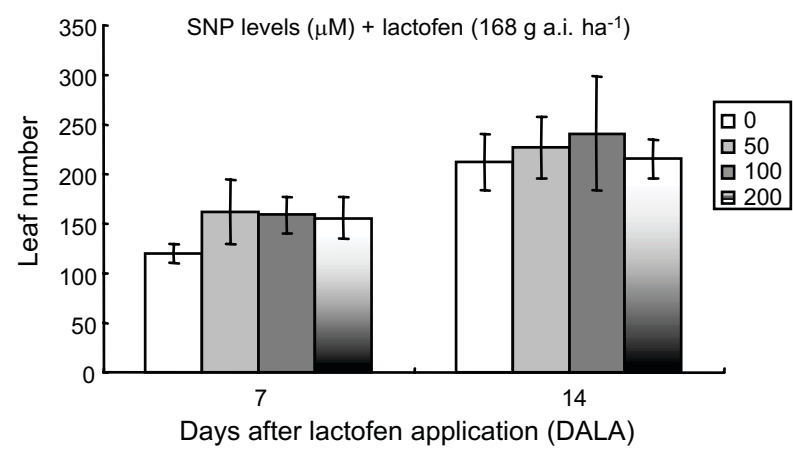

Figure 3 - Leaflet number of soybean (Glycine max) plants pretreated with $\operatorname{SNP}(0,50,100$, and $200 \mu \mathrm{M})$, followed by lactofen (168 g a.i. ha- ${ }^{-1}$ ), at 7 and 14 days after lactofen application (DALA). Means of four replicates.

phytotoxicity visual differences were detected considering the general aspect of the plants (data not shown). Damião Filho et al. (1992) also reported that lactofen can lead to wrinkling of developing leaflets in soybean crop. Furthermore, Roman (2000) stated that diphenylethers cause wrinkling and spots in soybean leaves few hours after application, which can result in tissue necrosis and leaf
(A)

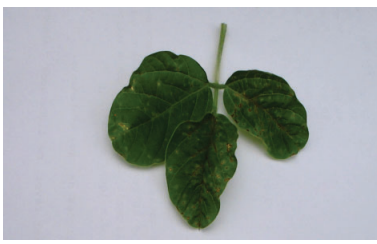

(B)
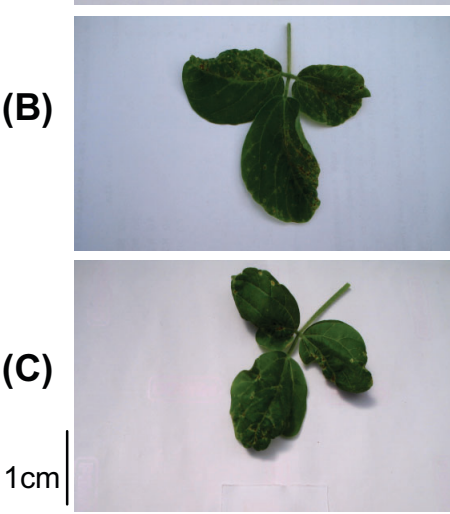

0
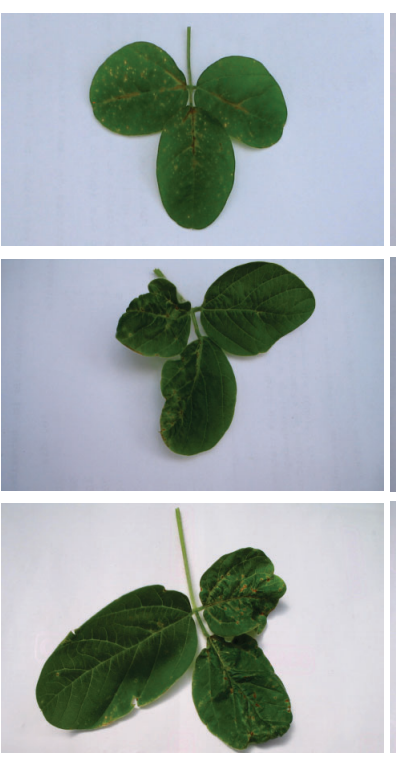

50
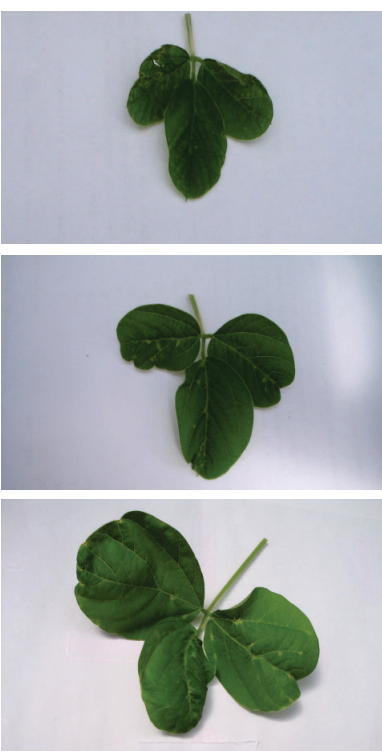

100
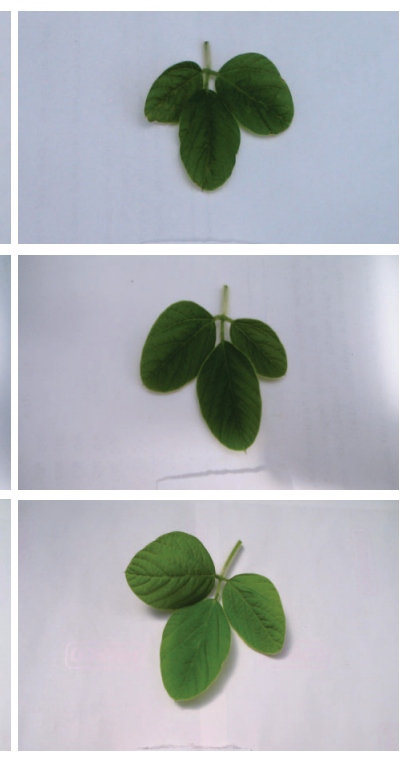

200

SNP $(\mu \mathrm{M})+$ lactofen $(168 \mathrm{~g}$ a.i. ha-1)

Figure 4 - General appearance of young trifoliolate leaves of soybean (Glycine max) plants pretreated with different levels of SNP $(0,50,100$, and $200 \mu \mathrm{M})$, followed by lactofen (168 g a.i. ha $\left.{ }^{-1}\right)$, at 2 (4A), 4 (4B) and 7 (4C) days after lactofen application (DALA) 
blight. In addition, high soil moisture, air temperature and relative humidity cause thinness in the leaf cuticle, which allows higher herbicide uptake by the plants and leads to higher phytotoxic effects in both crop and weeds. Thus, it can be suggested that NO had protective effect against the leaf injury caused by lactofen application in the present study. Similarly, Beligni \& Lamattina (1999b) observed that potato plants pretreated with 100 $\mu \mathrm{M}$ SNP were protected against chlorosis, necrosis, and leaf abscission resultant of diquat application.

Considering leaf blades, there was a reduction in total soluble sugar levels between 7 and 14 DALA in plants treated only with lactofen and in those pretreated with $50 \mu \mathrm{M}$ SNP (Figure 5A). When the highest SNP levels (100 and $200 \mu \mathrm{M}$ ) were sprayed, no soluble sugar alteration was observed between the evaluated periods. For stems plus petioles (Figure 5B), total soluble sugar levels decreased between 7 and 14 DALA only in plants that were not pretreated with SNP. However, these levels were lower in SNP-pretreated plants at 7 DALA and did not alter at 14 DALA. It must be emphasized that plants treated only with lactofen presented the lowest total soluble sugar levels at 14 DALA in leaf blades and stems plus petioles. Conversely, such plants had the highest levels of this variable in roots at the same period (Figure 5C). For leaf blades and stems plus petioles, total soluble sugar levels considerably reduced in plants that were not pretreated with SNP but kept low at 7 and 14 DALA in the presence of NO.

Total and reducing soluble sugar levels had similar behaviors, not only in leaf blades but also in stems plus petioles. Thus, reducing soluble sugar levels decreased in plants that were not pretreated with SNP (Figures 6A and 6B) and in those pretreated with $50 \mu \mathrm{M}$ (Figure 6A). For roots (Figure 6C), reducing soluble sugar levels decreased in plants pretreated with $100 \mu \mathrm{M}$ SNP, which was considered an isolated effect.
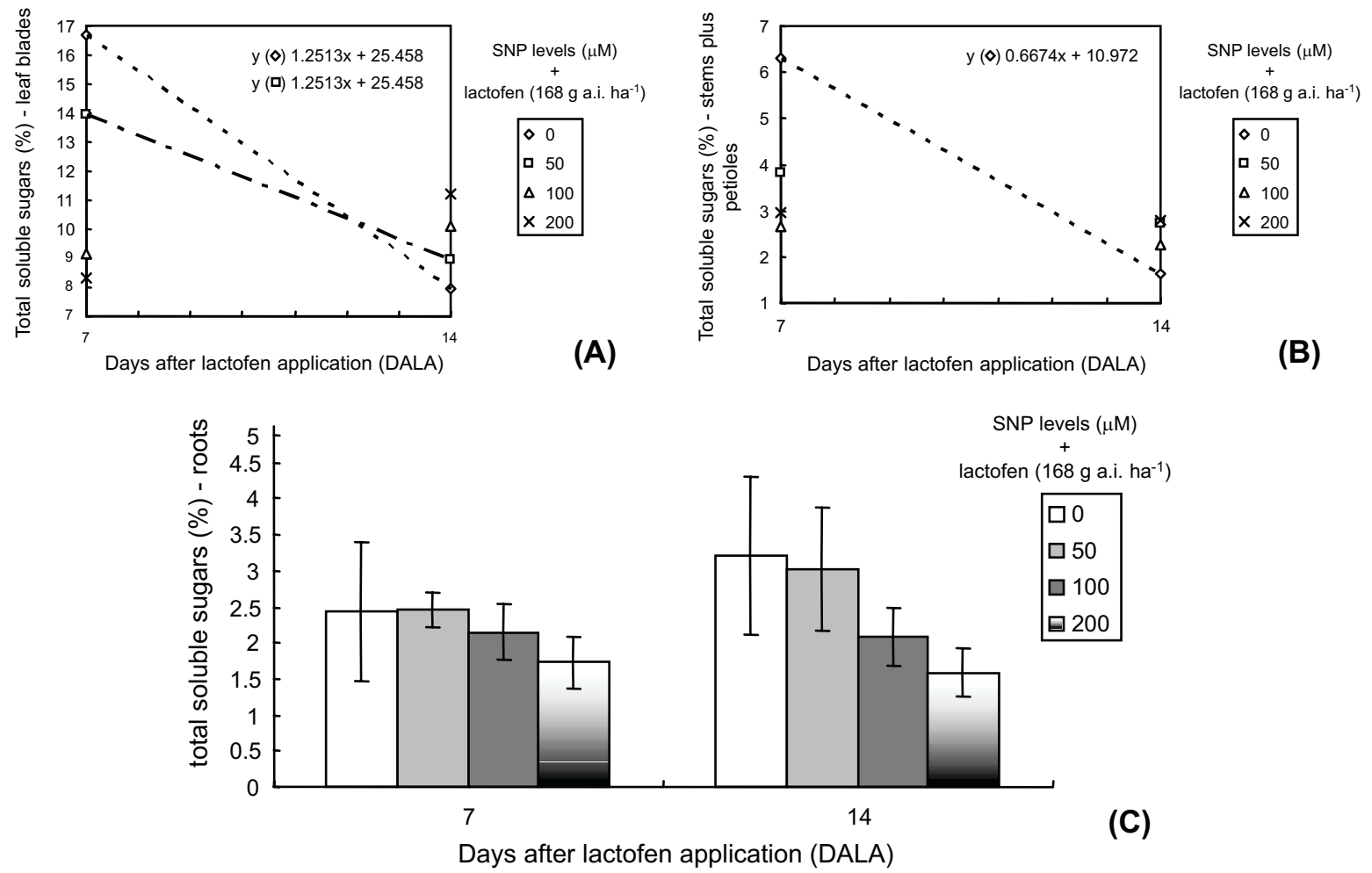

actofen (168 g a.i. ha-1)

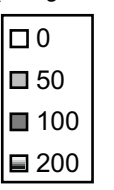

(C)

Figure 5 - Total soluble sugar levels (\%) in leaf blades (A), stems plus petioles (B), and roots (C) of soybean (Glycine max) plants pretreated with different levels of $\operatorname{SNP}(0,50,100$, and $200 \mu \mathrm{M})$, followed by lactofen $\left(168 \mathrm{~g} \mathrm{a} . \mathrm{i}\right.$. ha $\left.{ }^{-1}\right)$, at 7 and 14 days after lactofen application (DALA). Means of four replicates. 

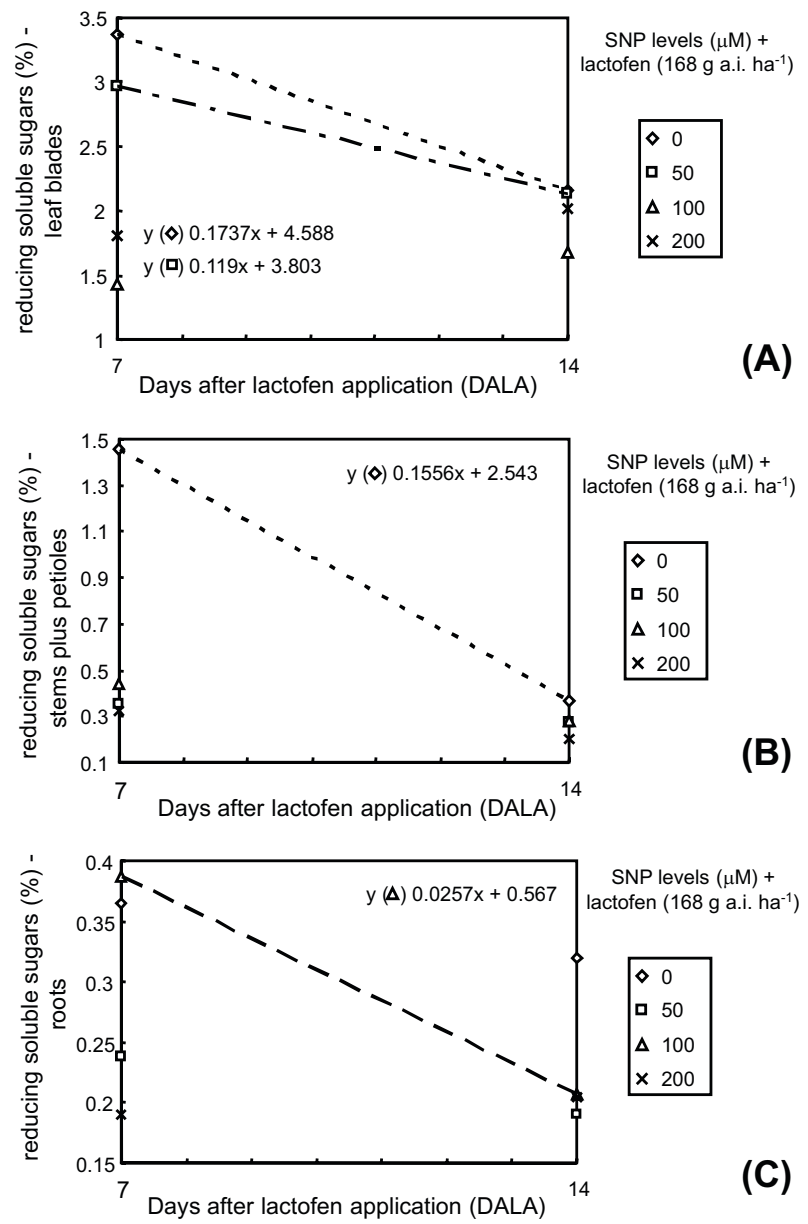

Figure 6 - Reducing soluble sugar levels (\%) in leaf blades (A), stems plus petioles (B), and roots (C) of soybean (Glycine max) plants pretreated with different levels of $\operatorname{SNP}(0,50$, 100 , and $200 \mu \mathrm{M})$, followed by lactofen (168 g a.i. ha-1), at 7 and 14 days after lactofen application (DALA). Means of four replicates

In general, plants that were not pretreated with SNP had higher reducing soluble sugar levels in leaf blades, stems plus petioles, and roots in the present study. Such results suggest that the levels of total and reducing soluble sugars were kept low in the presence of NO.

Soluble sugars seem to play an ambiguous role concerning ROS. First, they can be related to the metabolic pathways in which these compounds are produced. On the other hand, they can feed the metabolic NADPH production, such as in pentose phosphate oxidative pathway, which can contribute to ROS scavenging (Couée et al., 2006).
However, there are reports on different stress situations directly or indirectly causing ROS accumulation, such as pathogen attack, drought, salt stress, water stress, treatment with abscisic acid, low temperatures, or energetic excitation excess, also associated with soluble sugar accumulation, which has usually been considered a plant adaptive response to those conditions (Bartels \& Sunkar, 2005; Seki et al., 2007). Since NO is capable of scavenging ROS produced in adverse situations, as well as ending chainpropagated reactions (van Breusegem et al., 2001; Beligni \& Lamattina, 1999c; Leshem, 2000), the low soluble sugar levels detected in SNP-pretreated plants in the present study indicate that NO had a protective effect on soybean plants through scavenging ROS produced by lactofen. In another experiment, we also observed that NO was capable of scavenging ROS generated by lactofen in soybean plants, since it avoided photosynthetic pigment breakdown although lipid peroxidation was not completely interrupted. Consequently, ROS scavenging by NO leads not only to a lower availability of substrate for the antioxidant enzymes superoxide dismutase (SOD, EC 1.15.1.1), catalase (CAT, EC 1.11.1.6) and peroxidase (POD, EC 1.11.1.7), which are essential for plant protection against oxidative stress, but also to the absence of glutathione S-transferase (GST, EC 2.5.1.18) induction by $\mathrm{H}_{2} \mathrm{O}_{2}$ (Ferreira et al., 2010).

In general, SNP-pretreated plants tended to present higher dry matter at 7 DALA (Figure 7); however, at 14 DALA, these plants tended to have the lowest values of total dry matter and dry matter of the different organs. These results, again, suggest that NO led to slower growth in soybean plants, as verified for root length.

Roman (2000) stated that diphenylether herbicides cause a transitory interruption in soybean growth few hours after application due to injuries such as leaf wrinkling and spots, which can result in tissue necrosis and leaf blight. However, plants usually restart growing after three or four weeks. Similarly, Ross \& Lembi (1998) mentioned that the plant can recover, although symptomatology in lactofen-tolerant species is characterized by browning or chlorosis, with posterior evolution 

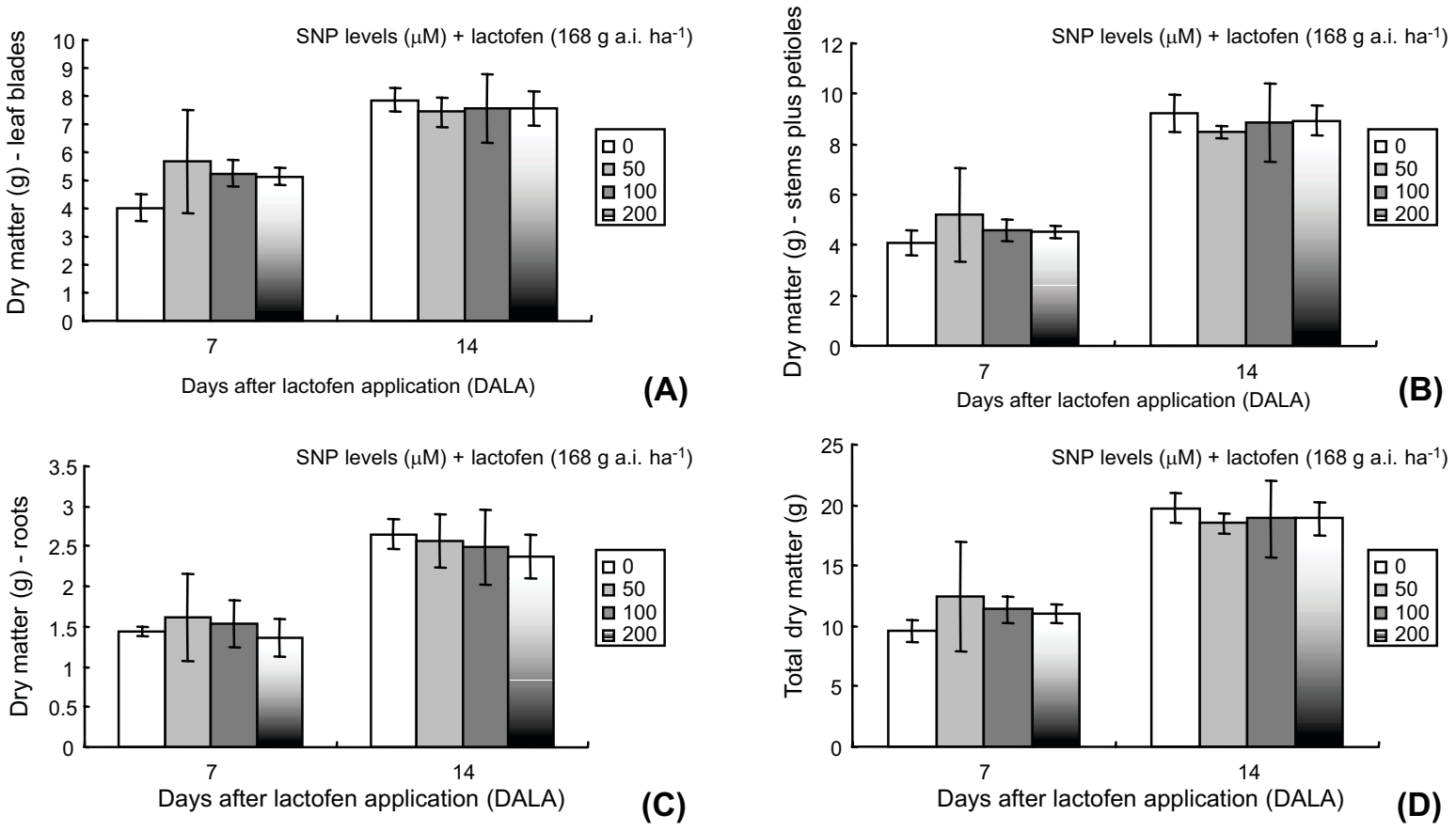

Figure 7 - Dry matter (g) of leaf blades (A), stems plus petioles (B), roots (C) and total dry matter (D) of soybean (Glycine max) plants pretreated with different levels of $\operatorname{SNP}(0,50,100$, and $200 \mu \mathrm{M})$, followed by lactofen $\left(168 \mathrm{~g}\right.$ a.i. ha $\left.\mathrm{g}^{-1}\right)$, at 7 and 14 days after lactofen application (DALA). Means of four replicates.

to necrosis in leaf sites affected by the application. This fact was also detected in the present study, in which plants treated only with lactofen had greater root length, leaflet number, total dry matter, and dry matter of different organs between 7 and 14 DALA. Soybean plant recovery in the presence of herbicide was also evidenced by the decrease in total and reducing soluble sugar levels in leaf blades and stems plus petioles between 7 and 14 DALA, which indicates lower stress degree in those plants at the end of the evaluation.

SNP pretreatment was considered beneficial to soybean plants, since NO reduced the injury visual symptoms caused by lactofen in young leaflets through ROS scavenging, which was confirmed by the constantly low levels of total and reducing soluble sugar due to NO action. It must be emphasized that no interaction between SNP levels + lactofen $x$ DALA was detected for the evaluated phytometric aspects, although physiological functions of NO in plants have been widely reported in the literature. Nevertheless, the present results suggest that NO led to slower growth in soybean plants. This fact, in addition to plant recovery after lactofen application, suggests that further studies are needed to clarify the mechanisms through which NO can act signaling the stress caused by lactofen in soybean crop.

\section{ACKNOWLEDGEMENTS}

The authors thank the Coordination for the Improvement of Higher Education Personnel (CAPES) for the financial support of this work.

\section{LITERATURE CITED}

BARROS, A. C.; UEDA, A.; SCHUMM, K. C. Eficiência e seletividade do lactofen em mistura com outros latifolicidas, no controle de plantas daninhas na cultura da soja. R. Bras. Herbic., v. 1, n. 1, p. 79-84, 2000

BARTELS, D.; SUNKAR, R. Drought and salt tolerance in plants. Crit. Rev. Plant Sci., v. 24, n. 1, p. 23-58, 2005.

BELIGNI, M. V.; LAMATTINA, L. Is nitric oxide toxic or protective? Trends Plant Sci., v. 4, n. 8, p. 299-300, 1999c. 
BELIGNI, M. V.; LAMATTINA, L. Nitric oxide counteracts cytotoxic processes mediated by reactive oxygen species in plant tissues. Planta, v. 208, n. 3, p. 337-344, 1999a

BELIGNI, M. V.; LAMATTINA, L. Nitric oxide in plants: the history is just beginning. Plant Cell Environ., v. 24, n. 3, p. 267-278, 2001.

BELIGNI, M. V.; LAMATTINA, L. Nitric oxide protects against cellular damage produced by methylviologen herbicides in potato plants. Nitric Oxide: Biol. Chem., v. 3, n. 3, p. 199-208, 1999b.

BELIGNI, M. V.; LAMATTINA, L. Nitric oxide stimulates seed germination and de-etiolation, and inhibits hypocotyl elongation, three light-inducible responses in plants. Planta, v. 210, n. 3 , p. $215-221,2000$.

COUÉE, I. et al. Involvement of soluble sugars in reactive oxygen species balance and responses to oxidative stress in plants. J. Exper. Bot., v. 57, n. 3, p. 449-459, 2006

CREPALDI, I. C. et al. Composição nutricional do fruto de licuri (Syagrus coronata (Martius) Beccari). R. Bras. Bot., v. 24, n. 1, p. $155-159,2001$

DAMIÃO FILHO, C. E.; CORSO, G. M.; ANDRADE, V. M. M. Efeitos do herbicida lactofen sobre três cultivares de soja. I. Alterações morfológicas externas e internas das folhas. Planta Daninha, v. 10, n. 1, p. 17-24, 1992.

DEL RÍO, L. A.; CORPAS, F. J.; BARROSO, J. B. Nitric oxide and nitric oxide synthase activity in plants.

Phytochemistry, v. 65, p. 783-792, 2004.

DUBOIS, $M$. et al. Colorimetric method for determination of sugars and related substances. Anal. Chem., v. 28, p. 350$356,1956$.

FERREIRA, L. C.; CATANEO, A. C. Nitric oxide in plants: a brief discussion on this multifunctional molecule. Sci. Agric., v. 67, n. 2 , p. $236-243,2010$

FERREIRA, L. C. et al. Nitric oxide reduces oxidative stress generated by lactofen in soybean plants. Pestic. Biochem. Physiol., v. 97, n. 1, p. 47-54, 2010

FLORYSZAK-WIECZOREK, J. et al. Do nitric oxide donors mimic endogenous NO-related response in plants? Planta, v. 224 , n. 6 , p. $1363-1372,2006$

GOUVÊA, C. M. C. P. et al. NO-releasing substances that induce growth elongation in maize root segments. Plant Growth Reg., v. 21, n. 1, p. 183-187, 1997.

HALLIWELL, B.; GUTTERIDGE, J. M. C. Oxygen toxicity, oxygen radicals, transition metals and disease. Biochem. J., v. 219, n. 1, p. $1-14,1984$.
HU, X. et al. Nitric oxide mediates gravitropic bending in soybean roots. Plant Physiol., v. 137, n. 2, p. 663-670, 2005

HUNG, K. T.; CHANG, C. J.; KAO, C. H. Paraquat toxicity is reduced by nitric oxide in rice leaves. J. Plant Physiol., v. 159, n. 1, p. 159-166, 2002.

KOPYRA, M.; GWÓZDZ, F. A. Nitric oxide stimulates seed germination and counteracts the inhibitory effect of heavy metals and salinity on root growth of Lupinus luteus. Plant Physiol. Biochem., v. 41, p. 1011-1017, 2003.

LAMATTINA, L. et al. Nitric oxide: the versatility of an extensive signal molecule. Ann. Rev. Plant Biol., v. 54, p. 109-136, 2003.

LESHEM, Y. Y. Nitric oxide in plants. Occurrence, function and use. Dordrecht: Kluwer Academic Publishers, 2000. 180 p

MATRINGE, M. et al. Protoporphyrinogen oxidase as a molecule target for diphenyl ether herbicides. Biochem. J., v. 260, n. 1, p. $231-235,1989$.

MEROTTO JUNIOR, A.; VIDAL, R. A. Herbicidas inibidores de PROTOX. In: VIDAL, R. A.; MEROTTO JUNIOR, A. (Eds.). Herbicidologia. Porto Alegre: Evangraf, 2001. p. $69-86$

MITTLER, R. et al. Reactive oxygen gene network of plants. Trends Plant Sci., v. 9, n. 10, p. 490-498, 2004.

NOCTOR, G.; FOYER, C. Ascorbate and glutathione: keeping active oxygen species under control. Ann. Rev. Plant Physiol. Plant Molec. Biol., v. 49, p. 249-279, 1998.

PAGNUSSAT, G. C. et al. Nitric oxide is required for root organogenesis. Plant Physiol., v. 129, p. 954-956, 2002.

PALLET, K. E.; YOUNG, A. J. Carotenoids. In: ALSCHER, R. G.; HESS, J. L. (Eds.). Antioxidants in higher plants Boca Raton: CCR Press, 1993. p. 91-110.

RODRIGUES, B. N.; ALMEIDA, F. L. S. Guia de herbicidas. 4.ed. Londrina: IAPAR, 1998. 648 p.

ROMAN, E. S. Estresses ocasionados por fitotoxicidade de herbicidas. In: BONATO, E. R. (Ed.). Estresses em soja. Passo Fundo: Embrapa Trigo, 2000. p. 103-143.

ROSS, M. A.; LEMBI, C. A. Applied weed science. 2.ed Upper Saddle River: Prentice Hall, 1998. 452 p.

SAS Institute - The statistical analysis system. 12.ed. Cary: 1996

SEKI, M. et al. Regulatory metabolic networks in drought stress responses. Current Opinion Plant Biol., v. 10, n. 3 , p. 296-302, 2007. 
SMIRNOFF, N.; CONKLIN, P. L.; LOEWUS, F. A. Biosynthesis of ascorbic acid in plants. Ann. Rev. Plant Physiol. Plant Molec. Biol., v. 52, p. 437-467, 2001.

SOMOGY-NELSON, M. A new reagent for determination of sugars. J. Biol. Chem., v. 160, n. 1, p. 61-63, 1945. van BREUSEGEM, F.et al. The role of active oxygen species in plant signal transduction. Plant Sci., v. 161, p. 405-414, 2001.

WATANABE, $\mathrm{K}$. et al. Changes in fatty acid composition of neutral lipid in mung bean cotyledons by oxyfluorfen-induced peroxidation. Pestic. Biochem. Physiol., v. 69, n. 1, p. 166-173, 2001. 